\title{
実習生とともに取り組む薬局におけるセルフメディケーション推進活動
}

\author{
坂口眞弓 $a, b$
}

\section{Self-medication Activities in a Community Pharmacy for Student Pharmacist Training}

\author{
Mayumi Sakaguchi ${ }^{a, b}$ \\ ${ }^{a}$ Midori Phamacy; 4-21-9 Kuramae, Taito-ku, Tokyo 111-0051, Japan: and ${ }^{b}$ Asakusa \\ Pharmaceutical Association; 2F 4-34-9 Kuramae, Taito-ku, Tokyo 111-0051, Japan.
}

(Received September 13, 2015)

\begin{abstract}
Japan's Ministry of Health, Labour and Welfare published "the required function and the desired operating form of a pharmacy" and proposed that "a pharmacy should demonstrate a positive role for the promotion of self-medication". In the future, it will be indispensable to pharmacies that pharmacists play a role not only in dispensing medicine but also in serving a central health-station role in the community, including promoting the self-selection of proper OTC medications for the maintenance of health. My pharmacy in a traditional area in Tokyo carries OTC drugs, health and nursing care goods, medical supplies, etc. besides dispensing medicine by prescription. Moreover, a "sample measurement room" where a person can conduct a blood test by self-puncture was prepared in April of 2014. In addition, my pharmacy has held "health consultation meetings" for patients in collaboration with a registered dietitian, as well as "meetings for briefing sessions on how to better take or administer medicines" for parents of infants, etc. These activities have been useful to local residents in the prevention of lifestyle-related diseases and in promoting a better understanding of medicine. Moreover, on-site student trainees from schools of pharmacy are helping with planning, data collection, and explanation on the days of these meetings. For trainees from schools of pharmacy, participating in these activities is important to becoming a pharmacist trusted at the community level in the future.
\end{abstract}

Key words_— student trainee; community pharmacy service; self-medication

\section{1. はじめに}

平成 26 年 1 月 21 日，厚生労働省医薬食品局総務 課より「薬局の求められる機能とあるべき姿」1)が 公表され，その中には薬局の役割として，

・ 最適な薬物療法を提供する医療の担い手とし ての役割

・ 医療の質の確保・向上や医療安全の確保の観 点から，医療機関等と連携してチーム医療を積 極的に取り組むこと

・ 在宅医療において，地域における医薬品等の 供給体制や適切な服薬支援を行う体制の確保 · 充実

- 医薬品や医療・衛生材料等の提供拠点として

a夕どり薬局（干111-0051 東京都台東区蔵前 4-21-9), $b$ 浅草薬剂師会（干111-0051 東京都台東区蔵前 4-34-9 2F)

e-mail: skguchi@aol.com

本総説は, 日本薬学会第 135 年会シンポジウムS36 で 発表した内容を中心に記述したものである.
の役割に留まらず, 後発品の使用促進や残薬解 消といつた医療の効率化について，より積極的 な関与

・ セルフメディケーションの推進のために, 地 域に密着した健康情報の拠点として積極的な役 割を発揮

- 患者の治療歴のみならず，生活習慣も踏まえ た全般的な薬学的管理に責任を持つこと が揭げられており，薬局に対して国民のセルフメ ディケーションの推進に尽力し，健康情報の拠点と しての活動が求められている.

これからの薬局は, 調剤を主とする「かかりつけ 薬局」の機能だけではなく, 地域住民のファースト アクセスの場として，健康に関する相談を幅広く受 け付け, 病気の予防や健康づくりに貢献する「健康 サポート薬局」の機能を備えなければならない。

\section{2. みよ゙り薬局の取組み}

当薬局は, 処方箋調剂のほか, OTC 医薬品や衛 生・介護用品, 雑貨品の販売を行つている昔ながら 
Table 1. Healthcare Support Events in Midori Pharmacy

\begin{tabular}{|c|c|c|c|c|c|}
\hline & 年月日 & 対象 & 薬剤師からの説明 & 管理栄養士からの説明 & 実 演 等 \\
\hline \multirow{2}{*}{1} & \multirow{2}{*}{2014 年 2 月 } & \multirow{2}{*}{$\begin{array}{l}\text { 乳幼児 } \\
\text { の母親 }\end{array}$} & \multirow{2}{*}{ 薬の服用（使用）について } & & 服薬補助ゼリー試食 \\
\hline & & & & & 外用剂の使用法 \\
\hline \multirow{2}{*}{2} & \multirow{2}{*}{2014 年 7 月 } & \multirow{2}{*}{ 小学生 } & \multirow{2}{*}{ 薬の正しい使い方について } & & お菓子を使つた調剤体験 \\
\hline & & & & & 飲み合わせの実験 \\
\hline 3 & 2014 年 11 月 & 主婦 & 生活習慣病（糖尿病）について & 糖尿病予防の食事指導 & HbA1c 測定 \\
\hline \multirow{2}{*}{4} & \multirow{2}{*}{2015 年 3 月 } & \multirow{2}{*}{ 主婦 } & \multirow{2}{*}{ 生活習慣病（脂質異常症）について } & \multirow{2}{*}{ 脂質異常症予防の食指導 } & HbA1c 測定 \\
\hline & & & & & $\mathrm{LDL}-\mathrm{C} \cdot \mathrm{HDL}-\mathrm{C} \cdot \mathrm{TG} \cdot \mathrm{TC}$ 測定 \\
\hline \multirow{2}{*}{5} & \multirow{2}{*}{2015 年 7 月 } & \multirow{2}{*}{ 小学生 } & \multirow{2}{*}{ 薬の正しい使い方について } & & お菓子を使った調剤体験 \\
\hline & & & & & 飲み合わせの実験 \\
\hline
\end{tabular}

の地域の薬局である.

また, 平成 26 年 4 月には, 臨床検査技師法の改 正により，自己穿刺による血液検查を行う「検体測 定室」を設け，平均血糖值（HbA1c）を測定する 機器と脂質（HDL コレステロール， LDL コレステ ロール，中性脂肪，総コレステロール）を測定する 機器を設置し, 希望者への血液検査を実施している.

それらの業務を行うほか, 定期的に, 薬局のス ペースを利用して, 地域住民対象の健康支援イベン トを開催している（Table 1).

Table 1 の 1 のイベントは乳幼児の母親を対象に した「薬の飲み方・使い方の説明会」である。実際 に試してもらった服薬補助ゼリーの味見や, 保湿剤 とステロイド外用剤の塗り方の実習は参加者の興味 をひき，様々な意見交換ができた。

Table 1 の 2 と 5 のイベントは夏休みに開催する 小学生向けの「薬剤師体験会」で, 夏休みの自由研 究にも利用できるように, 薬剤師の仕事や薬につい ての説明を行っている. 飲み合わせの簡単な実験を 取り入れたり，子供用の白衣を着させてお菓子を 使つた調剤体験（Fig. 1）を行っている. 楽しみな がらも，薬剤師が身近な存在であることを小学生の 頃から知ってほしいという思いで開催している.

Table 1 の 3 と 4 のイベントは, 検体測定室で自 己穿刺による血液検査 (HbA1c, HDL コレステロー ル, LDL コレステロール, 中性脂肪, 総コレステ ロール等）を行い（Fig. 2), 検査結果が出るまで の 1 時間, 薬剂師から検査值や病気の説明をし, 管 理栄養士がテーマに合わせた食事作りについて説明 をする「健康相談会」である（Fig. 3)。このイべ

ントは, 自分の検査值を知り, 生活習慣病の理解, 早期発見, 生活習慣病を予防するための生活習慣改 善を目的として実施している.

\section{3. 実習生とともに…}

当薬局では, 毎期, 薬学生の実習受け入れをして いる.

学生には, 薬学教育モデル・コアカリキュラムの 「地域で活躍する薬剤師」の中の到達目標である 「地域住民に対する医薬品の適正使用の啓発活動に おける薬剤師の役割を説明できる」の実習として本 イベントに係わらせている.

企画段階から一緒に考え, 資料作りに係わらせ, 事前準備, 当日の進行, 説明を行わせた. 終了後, 5 名の実習生から感想を聞いた。

シナリオや資料を作成して実習生が思ったことと して，(1)対象者が興味を持つ内容にすること，(2)医 療用語など, 対象者が理解し易い言葉を用いること,

(3)対象者の目線に合わせて作成する工夫が必要であ ること, (4)自分の知識を広げる勉強の機会になった ことなどが挙がった。

イベントを実施した感想として, (1)対象者に正確 に伝えるために，自分自身が勉強したこと，(2)伝え

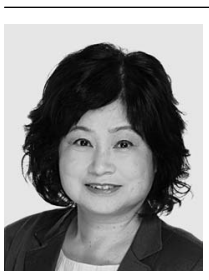

坂口眞弓
共立薬科大学卒業後, 東京大学医学部 附属病院勤務を経て, 現在, 浅草でみ ぞり薬局，みすじ薬局，ゆうま薬局を 開設. 一般社団法人 浅草薬剂師会 会 長. 一般社団法人 日本女性薬局経営者 の会 副会長. 東京薬科大学で客員教授 を務める傍ら, 千葉大学大学院医学薬 学府博士課程に在学中.「新しい薬局の 役割」をテーマに研究中. 


\section{処方 世}

(この処方せんは、どこの保険薬局でも有効です)

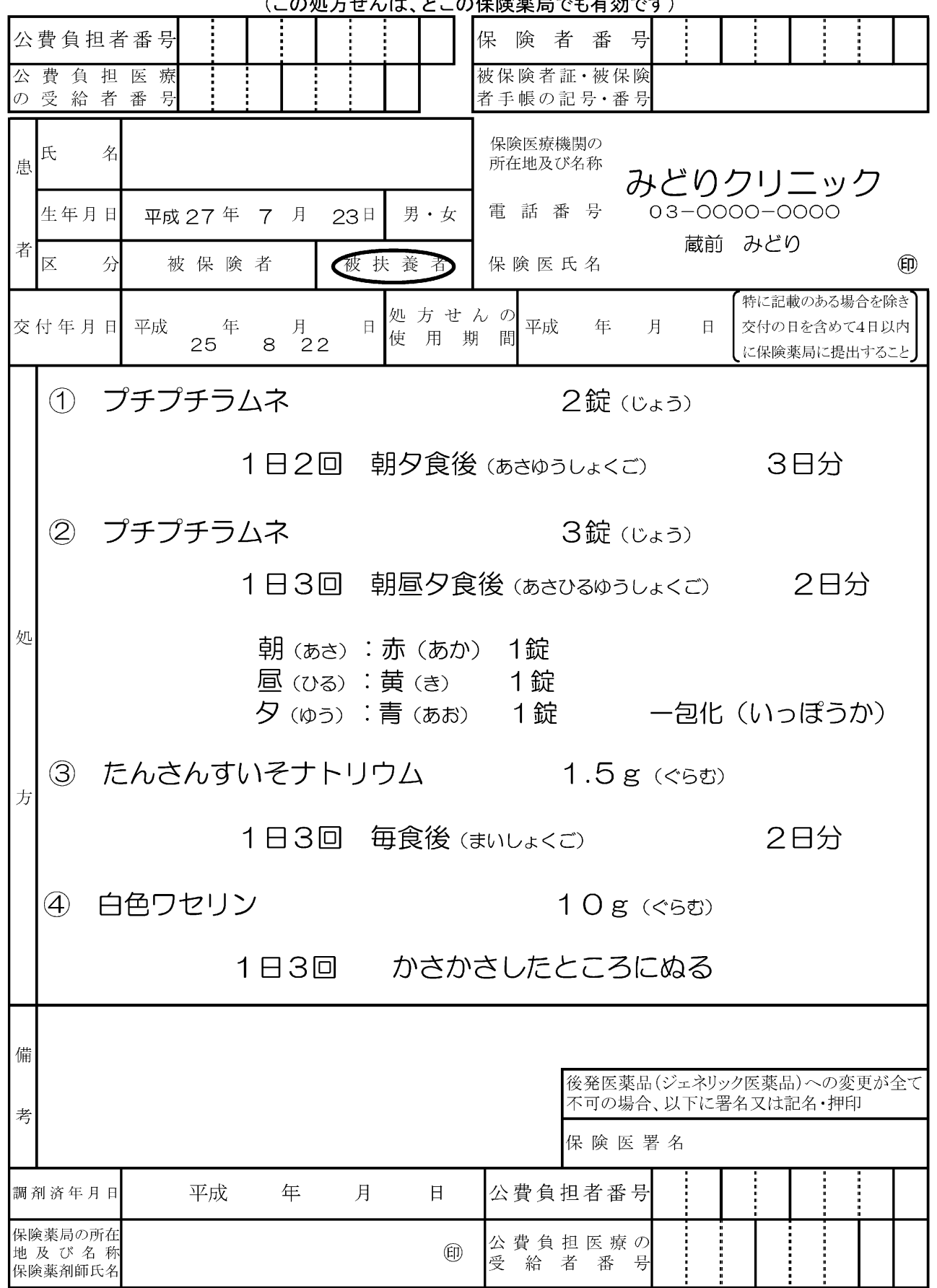

Fig. 1. Simulated Prescription for Child Experience as a Pharmacist

たいことが伝わったときの感激，(3)参加した小学生 が「薬剤師になりたい」と言つてくれたときの感激 とイベント成功の達成感を挙げていた.

また，薬剤師が地域で発信していくことについて， (1)健康を支援するために元気な人も含めて薬剤師の できる情報発信をすべきである，(2)自分達がどのよ
うな仕事を行っているのかを伝えたり，薬に限らず 地域の人々の健康に係わる活動を行っていくこと で，地域における薬剤師の存在を発信していく必要 がある，(3)薬剤師からの発信は地域とのつながりを 深めるとても大切な機会である, (4)薬剤師が要点を 把握し正確でわかり易い情報を伝達し地域との関係 


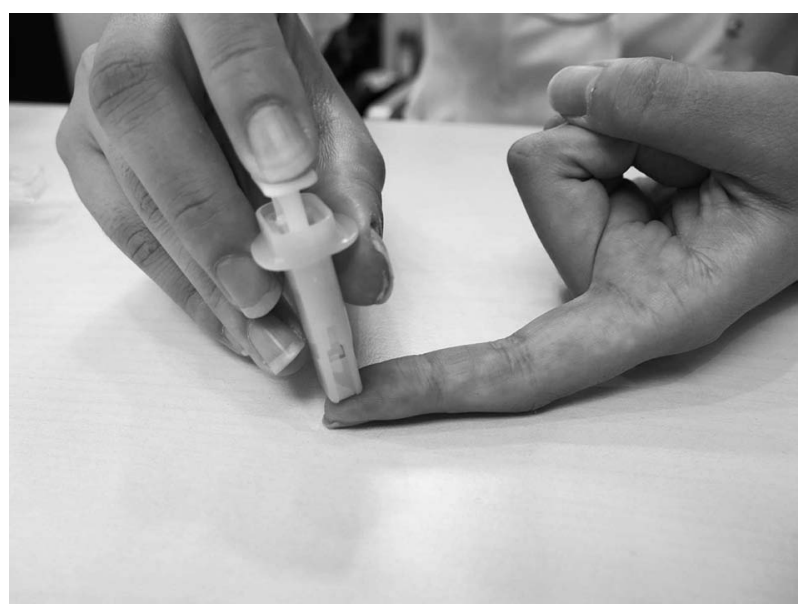

Fig. 2. Self-blood Sampling

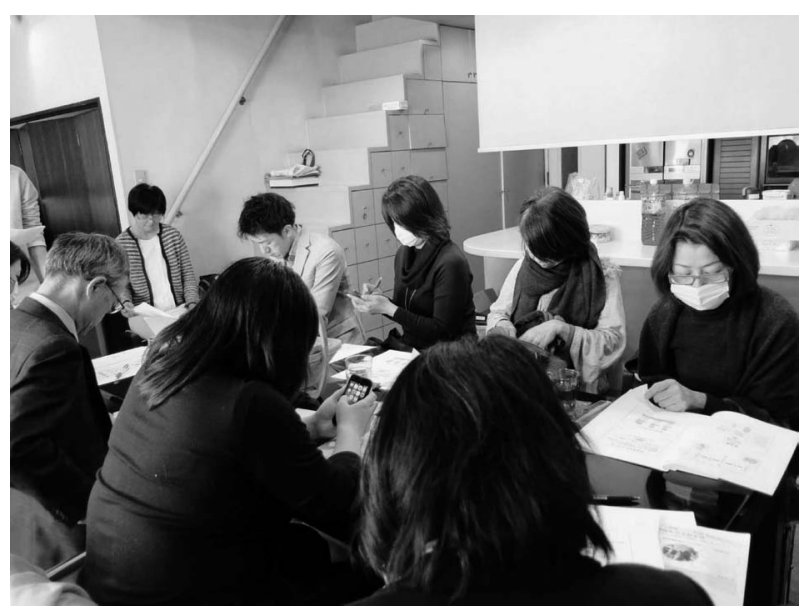

Fig. 3. Meeting for Health and Food in Midori Pharmacy

を密にできればよいなどの感想が挙がった.

これらの意見から， 2.5 力月の実習期間中，「地 域で信頼され，選ばれる薬剤師になるように」と言 い続けていることを学生がしっかり理解していると がわかり，指導者として大変嬉しく感じた.

4. おわりに

平成 27 年 6 月 18 日に開催された「第 2 回健康情
報拠点薬局のあり方に関する検討会」2)で，今後の 薬局の役割として「国民の病気の予防や健康づくり に貢献すること」が明記された。地域住民の健康支 援に関する取り組みは，ますます薬局の重要な役割 になると考えられる。

当薬局の取り組みは始めて 2 年ほどではあるが, このイベントを通し，医療の中で，薬剤師が何を考 え，何をしているか，また地域住民への健康支援に ついて発信をしていこうと考えている。薬剤師業務 への風当たりが強い現状ではあるが，地域住民が身 近にいる薬剤師から話を聞き，薬剤師の日頃の業務 を知ることは，地域医療の中での薬凨師の役割や必 要性を認識する重要な機会と考える.

そして, 将来薬剤師になる学生にも，住民から見 える薬凨師の活動をともに実施することにより，地 域で信頼される「かかりつけ薬凨師」を目指してほ しいと考える.

利益相反＼cjkstart開示すべき利益相反はない.

\section{REFERENCES}

1) The Ministry of Health, Labour and Welfare, "Yakkyoku no Motomerareru Kinou to Arubeki Sugata.”: 〈http://www.jsphcs.jp/ cont/14/0107-1.pdf $\rangle$, Japanese Society of Pharmaceutical Health Care and Sciences Web, cited 7 September, 2015.

2) The Ministry of Health, Labour and Welfare, Dai 2 Kai Kenkoujyouhoukyoten Yakkyoku no Arikata ni Kansuru Kentoukai, Shirou 1: 〈http: // www.mhlw.go.jp / file / 05-Shingikai11121000-Iyakushokuhinkyoku-Soumuka/siryou1. pdf $\rangle$, cited 7 September, 2015. 